\title{
THE DEVELOPMENT OF NEW TYPES OF SECONDARY PROTECTION FOR CONCRETE STRUCTURES EXPOSED TO EXTREME CONDITIONS
}

\author{
RAZVOJ NOVIH VRST SEKUNDARNE ZAŠČITE BETONSKIH \\ KONSTRUKCIJ IZPOSTAVLJENIH EKSTREMNIM POGOJEM
}

\author{
Amos Dufka, Tomáš Melichar, Jiří Bydžovský, Jan Vaněrek \\ Brno University of Technology, Faculty of Civil Engineering, Institute of Building Materials and Components, Veveří 95, \\ 60200 Brno, Czech Republic \\ dufka.a@fce.vutbr.cz
}

Prejem rokopisa - received: 2015-08-07; sprejem za objavo - accepted for publication: 2016-06-09

doi:10.17222/mit.2015.249

\begin{abstract}
During their use reinforced concrete structures are exposed to external influences. Nowadays, the reducing effect of these influences is usually ensured by secondary (barrier) protection. At present, coatings based on organic substances are commonly used. However, these types of secondary protection show substantial limits under extreme conditions. A method that has considerable potential to eliminate these disadvantages includes the application of secondary protection based on alkali-activated materials or geopolymers. This paper is focused on the development and optimisation of secondary protection (coating, plaster) based on alkali-activated materials intended for reinforced concrete structures to be exposed to highly chemically aggressive environments.
\end{abstract}

Keywords: coatings, alkali-activated substances, extreme conditions, agressive environment, durability of structures

Med uporabo so armirane betonske konstrukcije izpostavljene zunanjim vplivom. Danes se zmanjšanje vpliva teh učinkov zagotovi z uporabo sekundarne zaščite (prepreka). Običajno se uporabljajo premazi na osnovi organskih snovi. Vendar pa so te vrste sekundarne zaščite precej omejene pri ekstremnih pogojih. Metoda s potencialom da odpravi te pomanjkljivosti, vključuje uporabo sekundarne zaščite na osnovi alkalno-aktiviranih materialov ali geopolimerov. Članek obravnava razvoj in optimiranje sekundarne zaščite (premaz, omet) na osnovi alkalno aktiviranega materiala, namenjenega za armirane betonske konstrukcije, ki bodo izpostavljene kemijsko močno agresivnemu okolju.

Ključne besede: premazi, alkalno-aktivirane snovi, ekstremni pogoji, agresivno okolje, zdržljivost konstrukcij

\section{INTRODUCTION}

The conditions of exploitation are a key factor that limits the service life of building structures. These include both physico-mechanical influences (especially the synergistic effect of moisture and frost, increased temperature, etc.) and physico-chemical influences (aggressive substances, biotic agents, etc.). In principle, the resistance of building structures to negative influences can be ensured by several approaches, i.e., by structural design and the resistance of the materials used (i.e., by primary protection) and, especially, by having the negative influences of external environment onto the structure eliminated by a barrier protection. In particular, this includes coatings, sheets, etc. (i.e., secondary protection). Presently, a wide range of coating materials to protect reinforced concrete structures is available. In general terms, it comprises high-quality materials that, under standard conditions and withadequate maintenance, contribute considerably to the increased service life of the structure. This, however, only applies to buildings exposed to normal conditions.

If, however, the building structures are exposed to extreme conditions, a different situation will occur. In some types of chemically aggressive environments, for example, the coating materials based on organic substances feature distinct limits. The situation is even more distinctive in the buildings exposed to increased temperatures. This primarily applies to cases when the temperature changes are associated with a conspicuous gradient. Under such conditions, stresses may occur in the coating-substrate interface due to the different thermal coefficients of expansion as well as due to changes in the microstructure of the polymer matrix, and result in the separation of the coating from the substrate, cracking, etc.

The development of coating materials with a matrix based on alkali-activated substances, or geopolymers, seems to be a very viable material basis making it possible to solve the above problems. The coating based on alkali-activated slag presented in this article shall hereinafter be referred to as AAM coating.

The unique properties of alkali-activated materials provide assumptions for the development of new secondary protections intended for reinforced concrete constructions operated in extreme conditions (for instance, in environments of synergistic actuation of higher temperature and chemically aggressive substances, etc.). 
The alkali activated slag material being represented herein is intended as a secondary protection for reinforced concrete constructions. On that basis the properties of the developed AAM material are compared with an acrylate co-polymer-based coating intended just for the constructions exploited in chemically aggressive environments. In addition, the effect of the selected aggressive environment type is monitored on cement concrete without any secondary protection for comparison.

The developed material based on alkali-activated slag is not developed as repair mortar in this case but as secondary protection. Within this context the comparison of the properties of the secondary protection based on alkali-activated slag with a polymeric coating can therefore be considered as relevant.

\section{SPECIFICATION OF THE COATINGS BEING DEVELOPED}

In general terms, we can say that the coatings based on alkali-activated materials are made by the polycondensation of aluminosilicates at temperatures up to $100{ }^{\circ} \mathrm{C}$. The polymerisation includes the chemical reactions of aluminosilicates $\left(\mathrm{Al}^{3+}\right.$ in tetrahedral coordination) and alkaline polysilicates forming polymeric bindings $\mathrm{Si}-\mathrm{O}-\mathrm{Al}$. As a result, a solid and compact structure forming a dominant component of the matrix of the composite, or coating system, is created., ${ }^{1,2}$

This paper deals with the development of a coating system based on alkali-activated substances to be used for the protection of reinforced concrete structures exposed to extreme conditions. A typical example representing such extreme conditions includes the joint effect of chemically aggressive environments and increased temperature. For example, the structures forming an integral part of process lines for the production of chemicals and the like may be subject to such exposure. Due to the specifics of the above productions, the reinforced concrete structures are frequently loaded by a cyclic effect of increased temperatures for long periods and exposed, on practically a continuous basis, to the effects of aggressive chemicals. The above-mentioned facts have been taken into account during the development of the coating system.

\section{EXPERIMENTAL PART}

The previous researches made in this field have been followed by the development of an alkali-activated coating. In terms of the service life and functionality of the coating system being developed, its adhesion to the substrate represents one of key parameters. With regard to this fact, the alkali-activated matrix was modified by a polymer dispersion. The coating composition obtained by the optimisation process is shown in Table 1 . The optimisation process for AAM-based coating develop- ment follows the research presented in ${ }^{1-4}$. For instance, the effect of the water glass silicate module is examined in this case in relation to the slag chemical composition, further to the glass-phase content in it, etc. Optimizing the granulometry and the amount of filler used, for example, was based on data provided in ${ }^{5,6}$.

Table 1: Composition of AAM coating

Tabela 1: Sestava AAM premaza

\begin{tabular}{|c|c|}
\hline Coating component & Content of component $(w / \%)$ \\
\hline Water glass & 16 \\
\hline Polymer dispersion & 2 \\
\hline Slag & 31 \\
\hline $\begin{array}{c}\text { Filler - silica sand, fraction } \\
\text { of 0.45 mm }\end{array}$ & 44 \\
\hline Water & 7 \\
\hline
\end{tabular}

For the water glass used, a silicate modulus of 1.7 was applied. Primarily, the water glass silicate module drew from the findings presented in $1,4,5$. The chemical composition of the water glass is shown in Table 2.

Table 2: Chemical composition of water glass

Tabela 2: Kemijska sestava vodnega stekla

\begin{tabular}{|c|c|}
\hline Component of water glass & Content of component $(w / \%)$ \\
\hline $\mathrm{SiO}_{2}$ & $21.41 \%$ \\
\hline $\mathrm{Na}_{2} \mathrm{O}$ & $12.81 \%$ \\
\hline $\mathrm{K}_{2} \mathrm{O}$ & $0.62 \%$ \\
\hline $\mathrm{CaO}$ & $0.02 \%$ \\
\hline
\end{tabular}

The polymer dispersion used was based on vinyl acetate ethylene copolymer. For the chemical composition of the slag, please refer to Table 3.

Table 3: Chemical composition of slag

Tabela 3: Kemijska sestava žlindre

\begin{tabular}{|c|c|}
\hline Component of slag & Content of component $(w / \%)$ \\
\hline $\mathrm{CaO}$ & 35.9 \\
\hline $\mathrm{SiO}_{2}$ & 40.1 \\
\hline $\mathrm{Fe}_{2} \mathrm{O}_{3}$ & 6.9 \\
\hline $\mathrm{Al}_{2} \mathrm{O}_{3}$ & 8.2 \\
\hline $\mathrm{Na}_{2} \mathrm{O}$ & 2.1 \\
\hline $\mathrm{K}_{2} \mathrm{O}$ & 0.9 \\
\hline $\mathrm{P}_{2} \mathrm{O}_{5}$ & 1.4 \\
\hline $\mathrm{MgO}$ & 2.1 \\
\hline $\mathrm{MnO}$ & 0.3 \\
\hline
\end{tabular}

The experiments were aimed at the development of a coating to be resistant as much as possible to extreme conditions, i.e., to the synergistic effect of highly chemically aggressive environments and increased temperature. In particular, the coating was exposed to the saturated solution of ammonium sulphate with a part of ammonia sulphate not already dissolved in the suspension. The solution temperature was $50{ }^{\circ} \mathrm{C}$. The test samples were prepared so that the developed coating was applied to the concrete substrate using a roller (concrete class C30/37 was used). In order to assess the resistance 
of the AAM coating in an impartial manner, a commercially available coating based on acrylate copolymer was exposed to the same type of aggressive environment. We used a coating designed by its manufacturer to protect the surface of the reinforced concrete structures exploited in chemically aggressive environments. Here again, test samples were prepared so that the coating was applied on the substrate consisting of concrete, class C30/37. The coating was applied in accordance with the applicable product's technical data sheet (i.e., especially in regard to the coating consumption and the method of application). Furthermore, the effect of the test environment was tested directly on the uncoated concrete; again, concrete class C30/37 was used. For both coating types (i.e., the developed AAM coating and the commercially available coating based on acrylate copolymer) as well as for the uncoated concrete, two sets of test specimens were prepared. The samples of the first set were kept under laboratory conditions for the entire period of the experiment (i.e., $\mathrm{t}=20 \pm 2{ }^{\circ} \mathrm{C}, \varphi=50 \pm 5 \%$ ). The values found in these specimens were considered as a reference. The test samples of the second set were exposed to the saturated solution of ammonium sulphate at increased temperature for periods of 3 months and 6 months. The test solution was prepared with an excessive amount of ammonium sulphate that remained unsolved. The solution temperature was maintained at $50{ }^{\circ} \mathrm{C}$. Test samples aged for $28 \mathrm{~d}$ were placed in this aggressive environment.

In order to assess the effect of the test environment, individual test samples were then subject to the following determinations after the 3-month and 6-month exposures:

- Visual evaluation - the condition of coatings was primarily assessed in terms of the potential occurrence of cracks (ČSN EN ISO 4628-4) and blistering (ČSN EN ISO 4628-2). For the uncoated concrete, the appearance of the concrete surface layers was assessed;

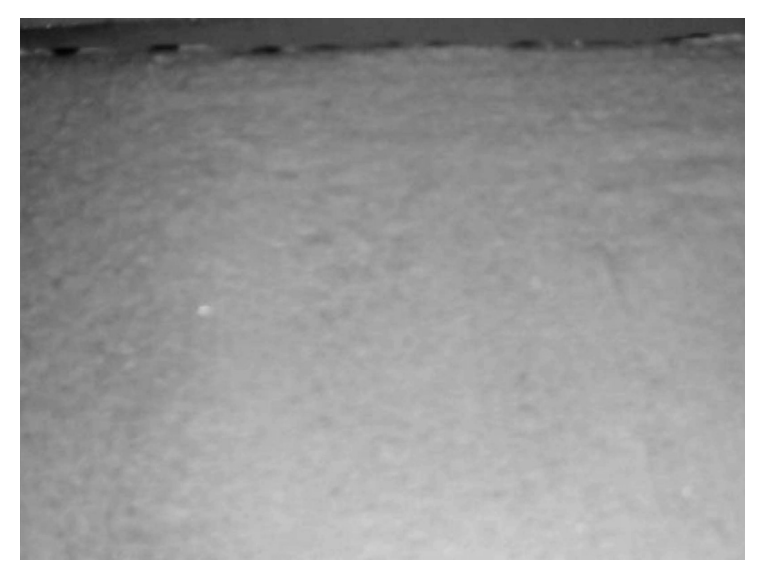

Figure 1: Macroscopic view of the structure of developed AMM coating prior to its exposure to aggressive environments

Slika 1: Makroskopski izgled konstrukcije z AMM-premazom pred izpostavitvijo agresivnemu okolju
- Determination of the coating thickness (ČSN EN ISO 2808);

- Determination of the coating adhesion to the substrate (ČSN EN ISO 4624). For the uncoated concrete, the tensile strength of the concrete surface layers was observed (ČSN 73 1318). During this test a disk with a $50-\mathrm{mm}$ diameter is glued on the surface of the concrete being evaluated and it is cut to clearly define the loaded area. During this test the defined area is loaded by tensile force up to the breakage limit of the tested material;

- Determination of the water-tightness of coatings (ČSN 73 2578). This test proves the coating system's ability to hold water in the liquid state. The test result is expressed as the amount of water that passed through the coating in the screeding materials (without any actuation of the hydrostatic pressure) within $30 \mathrm{~min}$; the unit is therefore 1 litre of water related to $1 \mathrm{~m}^{2}$ of the tested surface;

- Analyses of the microstructure using a scanning electron microscope (methodological procedure No. 30-33/1 by Brno University of Technology, Faculty of Civil Engineering).

The mentioned complex of the experiments followed de facto the stipulations of the standards involved in questions of the rehabilitation of reinforced concrete constructions ČSN EN 1504-1 and ČSN EN 1504-2.

\section{RESULTS \\ 4.1 Visual evaluation}

Attention was primarily paid to the evaluation of the condition of the surface layers of the tested samples. In the sample with the developed AAM coating, it was found that even the 6-month exposure to the test environment did not cause any changes to the coating that would prove its degradation due to aggressive substances. Even after the completion of the experiment, the coating structure remained practically identical. This

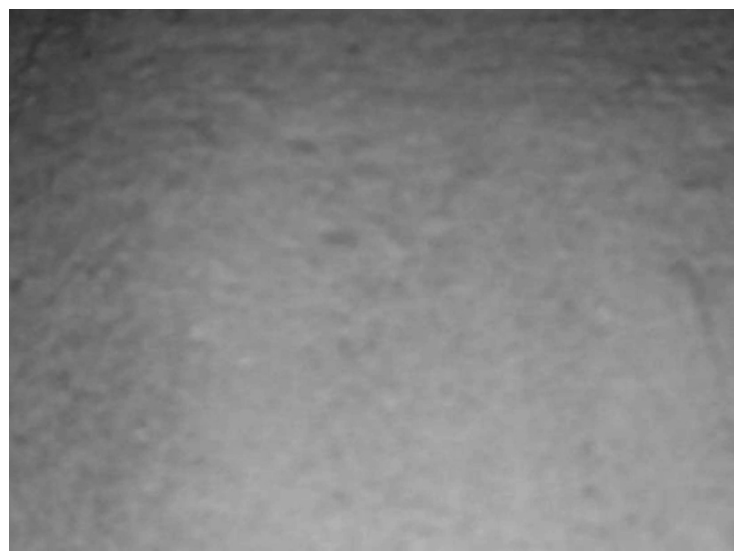

Figure 2: Macroscopic view of the structure of developed AMM coating after a 6-month exposure to ammonium sulphate

Slika 2: Makroskopski izgled konstrukcije z AMM premazom po šestih mesecih izpostavitve amonijevemu sulfatu 


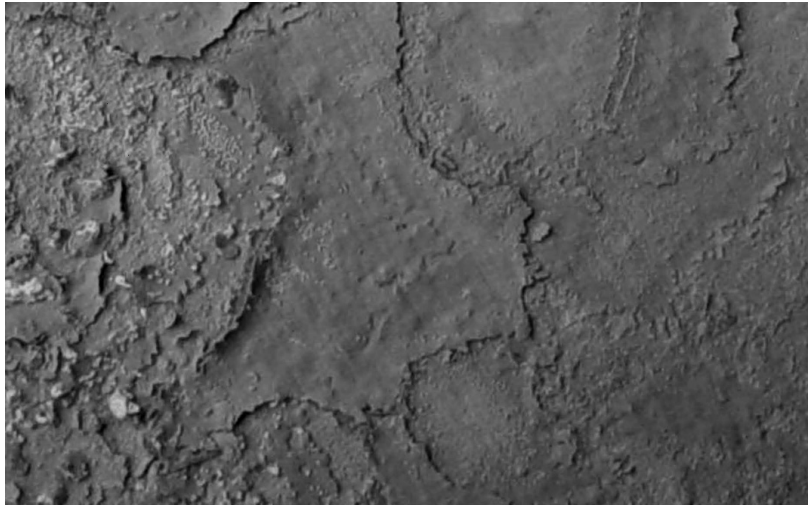

Figure 3: View of the macrostructure of coating based on acrylate copolymer after a 6-month exposure to the test environment

Slika 3: Izgled makrostrukture premaza na osnovi akrilatnega polimera po šestih mesecih izpostavljenosti preizkusnemu okolju

situation is documented in the following photographs (Figures 1 and 2):

It was concluded that even a 6-month exposure of the AAM coating would not cause any significant change in the structure of the surface layers of the AAM coating. In addition, the visual evaluation did not reveal any evident presence of cracks or any other defects. Yet, a different situation was found in the coating based on acrylate copolymer. In this case, a 6-month exposure to the solution of ammonium sulphate and an increased temperature resulted in the coating's degradation. This fact is documented in the following photographs (Figures 3 and 4). The evident destruction of the surface layers of the coating is shown in Figure 3. The destroyed surface layers of the coating film (i.e., flaking of the coating) and cracks are shown in Figure 4.

Furthermore, it was proven that the effect of the test environment on the concrete without secondary protection caused a significant degradation of the cement matrix. The visual evaluation revealed a change in the colour of surface layers, and especially the occurrence of cracks and local separations of surfaces layers (i.e., of

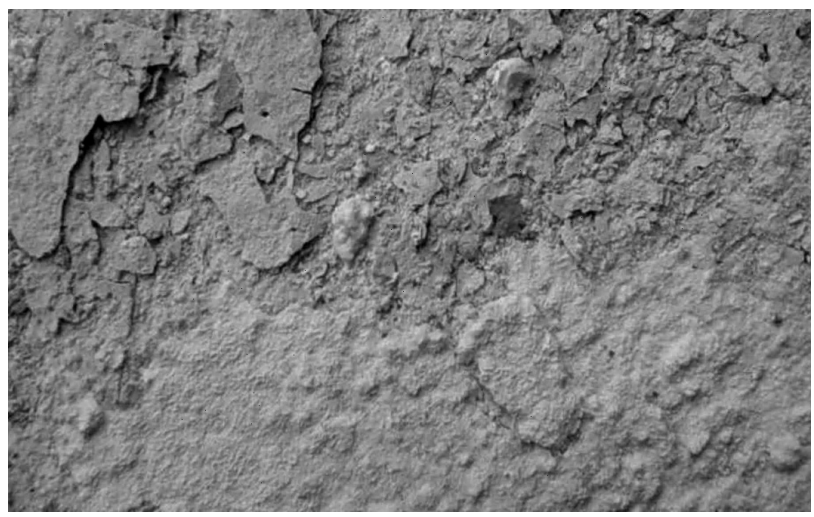

Figure 4: A 6-month exposure to the test environment caused the degradation of the coating based on copolymer acrylate

Slika 4: Šestmesečna izpostavljenost preizkusnemu okolju je povzročila degradacijo premaza na osnovi kopolimernega akrilata

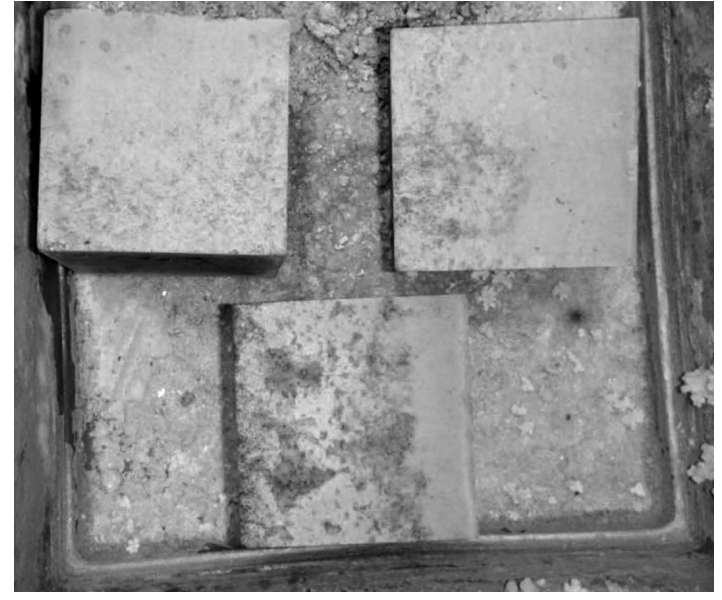

Figure 5: A 6-month exposure to the test environment caused a massive degradation of surface layers of uncoated concrete

Slika 5: Šestmesečna izpostavljenost preizkusnemu okolju je povzročila močno degradacijo površine betona brez premaza

concrete up to a depth of approx. $5 \mathrm{~mm}$ ) from the substrate (Figure 5).

\subsection{Determination of coating thickness}

Coating thickness is one of the key factors determining the protective function of the coating. Besides, it is a parameter, the monitoring of which, or monitoring of changes in coating thickness, makes it possible to carefully assess the development of the coating degradation due to the aggressive environment. The coating thickness was measured prior to placing the individual samples in the aggressive environment (the samples were $28 \mathrm{~d}$ old) and then after 3-month and 6-month exposures to aggressive environments. The coating thickness was measured using a cutting method and procedure according to the ČSN EN ISO 2808 standard. For the results of the coating thickness measurements, please refer to Table 4. The shown values represent an arithmetic mean of ten measurements.

Table 4: Coating thickness

Tabela 4: Debelina premaza

\begin{tabular}{|c|c|c|c|c|}
\hline \multirow{2}{*}{ Type of coating } & \multirow{2}{*}{ Placement } & \multicolumn{3}{|c|}{ Exposure time } \\
\hline & & $28 \mathrm{~d}$ & 3 months & 6 months \\
\hline \multirow{2}{*}{$\begin{array}{l}\text { Developed } \\
\text { AAM coating }\end{array}$} & $\begin{array}{c}\text { Laboratory } \\
\text { environment }\end{array}$ & $520 \mu \mathrm{m}$ & $510 \mu \mathrm{m}$ & $515 \mu \mathrm{m}$ \\
\hline & $\begin{array}{c}\text { Aggressive } \\
\text { environment }\end{array}$ & - & $500 \mu \mathrm{m}$ & $490 \mu \mathrm{m}$ \\
\hline \multirow{2}{*}{$\begin{array}{l}\text { Commercially } \\
\text { available coat- } \\
\text { ing based on } \\
\text { acrylate copo- } \\
\text { lymer }\end{array}$} & $\begin{array}{c}\text { Laboratory } \\
\text { environment }\end{array}$ & $410 \mu \mathrm{m}$ & $415 \mu \mathrm{m}$ & $410 \mu \mathrm{m}$ \\
\hline & $\begin{array}{l}\text { Aggressive } \\
\text { environment }\end{array}$ & - & $350 \mu \mathrm{m}$ & $290 \mu \mathrm{m}$ \\
\hline
\end{tabular}

\section{Evaluation}

It was proven that even a 6-month exposure would not cause any significant change of the thickness of the AMM coating. Yet, a different situation occurred in the commercially available coating. In this coating, the 
effect of the aggressive environment resulted in a thickness reduction by approximately $30 \%$. This finding is in full compliance with the visual evaluation that revealed a degradation of the coating based on acrylate copolymer (i.e., especially fissures, separations of surface layers of the coating, etc.). This degradation of the surface layers of the coating film, in particular, has then become the dominant cause of thickness reduction for the commercially available coasting.

\subsection{Determination of coating adhesion to a substrate}

Adhesion to a substrate is another parameter that is quite critical in terms of the protective function and service life of the coating. Coating-substrate adhesion was determined in accordance with the applicable provisions of the ČSN EN ISO 4624 standard. In addition, the effect of concentrated ammonium sulphate and increased temperature was tested in the uncoated concrete. The concrete was subjected to pull-off testing, and the tensile strength of the surface layers was determined using the procedure according to the ČSN 73 1318 standard.

For the results of the determination of coastingsubstrate adhesion, or a determination of the tensile strength of the concrete surface layers, please refer to Table 5. The values shown represent an arithmetic mean of five measurements.

Table 5: Determination of coating-substrate adhesion Tabela 5: Določanje adhezije premaz-podlaga

\begin{tabular}{|c|c|c|c|c|}
\hline \multirow{2}{*}{$\begin{array}{l}\text { Type of } \\
\text { material }\end{array}$} & \multirow{2}{*}{ Placement } & \multicolumn{3}{|c|}{ Exposure time } \\
\hline & & $28 \mathrm{~d}$ & 3 months & 6 months \\
\hline \multirow{2}{*}{$\begin{array}{l}\text { Developed } \\
\text { AAM coating }\end{array}$} & $\begin{array}{c}\text { Laboratory } \\
\text { environment }\end{array}$ & $2.1 \mathrm{MPa}$ & $2.4 \mathrm{MPa}$ & $2.6 \mathrm{MPa}$ \\
\hline & $\begin{array}{c}\text { Aggressive } \\
\text { environment }\end{array}$ & 一 & $2.2 \mathrm{MPa}$ & $2.0 \mathrm{MPa}$ \\
\hline \multirow{2}{*}{$\begin{array}{l}\text { Commercially } \\
\text { available } \\
\text { coating based } \\
\text { on acrylate } \\
\text { copolymer } \\
\end{array}$} & $\begin{array}{c}\text { Laboratory } \\
\text { environment }\end{array}$ & $2.9 \mathrm{MPa}$ & $3.0 \mathrm{MPa}$ & $2.9 \mathrm{MPa}$ \\
\hline & $\begin{array}{l}\text { Aggressive } \\
\text { environment }\end{array}$ & - & $1.6 \mathrm{MPa}$ & $0.9 \mathrm{MPa}$ \\
\hline \multirow{2}{*}{$\begin{array}{l}\text { Uncoated } \\
\text { concrete }\end{array}$} & $\begin{array}{c}\text { Laboratory } \\
\text { environment }\end{array}$ & $2.6 \mathrm{MPa}$ & $2.9 \mathrm{MPa}$ & $3.0 \mathrm{MPa}$ \\
\hline & $\begin{array}{c}\text { Aggressive } \\
\text { environment }\end{array}$ & 一 & $0.9 \mathrm{MPa}$ & $0.2 \mathrm{MPa}$ \\
\hline
\end{tabular}

\section{Evaluation}

It was concluded that the test environment caused a degradation of the uncoated concrete, which resulted, for example, in a distinct decrease in the tensile strength of the surface layers. A significant decrease in the coatingsubstrate adhesion after the exposure to the test environment was found for the coating based on acrylate copolymer. The coating material itself, not the coatingsubstrate interface, was the area in which the defects were mainly revealed after pull-off testing. The smallest decrease in adhesion to the substrate was detected in the AMM coating. In this type of coating, a 6-month exposure to the test environment caused only a decrease of approximately $25 \%$. The AAM coating-substrate interface was the area with the most frequent occurrence of defects.

\subsection{Determination of coating water-tightness}

The water-tightness of the coatings was determined using the procedure according to the ČSN 732578 standard. For the test results, please refer to Table 6; the values represent an arithmetic mean of five measurements.

Table 6: Coating water-tightness

Tabela 6: Vodotesnost premaza

\begin{tabular}{|c|c|c|c|c|}
\hline \multirow{2}{*}{ Type of coating } & \multirow{2}{*}{ Placement } & \multicolumn{3}{|c|}{ Exposure time } \\
\hline & & $28 \mathrm{~d}$ & 3 months & 6 months \\
\hline \multirow{2}{*}{$\begin{array}{l}\text { Developed AAM } \\
\text { coating }\end{array}$} & $\begin{array}{r}\mathrm{La} \\
\text { env }\end{array}$ & $0.91 . \mathrm{m}^{-2}$ & $0.91 . \mathrm{m}^{-2}$ & $0.81 . \mathrm{m}^{-2}$ \\
\hline & $\begin{array}{l}\text { Agg } \\
\text { envir }\end{array}$ & - & 1.01 & $1.11 . \mathrm{m}^{-2}$ \\
\hline \multirow{2}{*}{$\begin{array}{c}\text { Commercially } \\
\text { available coating } \\
\text { based on acrylate } \\
\text { copolymer }\end{array}$} & $\begin{array}{l}\text { Lab } \\
\text { envi }\end{array}$ & $0.21 . \mathrm{m}^{-2}$ & $0.21 . \mathrm{m}^{-2}$ & $0.21 . \mathrm{m}^{-2}$ \\
\hline & $\begin{array}{c}\text { Aggressive } \\
\text { environment }\end{array}$ & - & $0.61 . \mathrm{m}^{-2}$ & $0.91 . \mathrm{m}^{-2}$ \\
\hline
\end{tabular}

\section{Evaluation}

The testing shows that the water-tightness of the developed AAM coating is lower when compared to the acrylate coating. In terms of water-tightness, the AAM coating satisfied the requirements for vapour-permeable coatings, while the coating based on acrylate copolymer has, in terms of this parameter, satisfied the requirements for vapour-tight coatings. However, it was proven that the water-tightness of the coating based on acrylate copolymer rapidly decreased when exposed to the test environment. A 6-month exposure to the test environment caused a more than four times lower water-tightness of the coating based on the acrylate copolymer. In

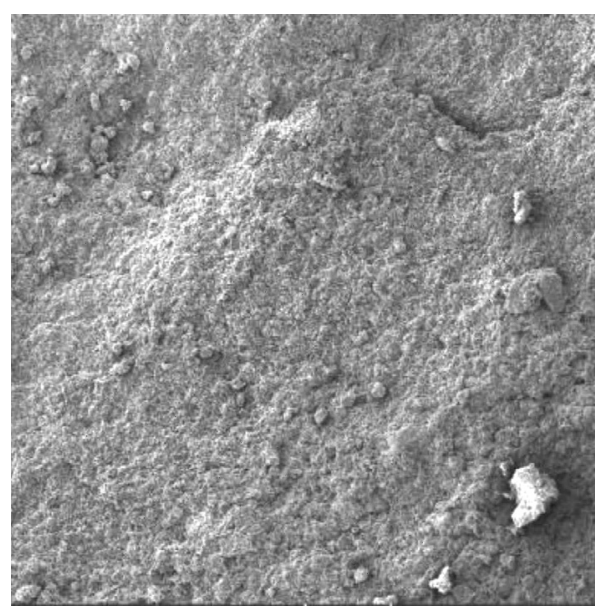

Figure 6: View of the microstructure of AAM-based coating. The coating structure is compact. $100 \times$ magnification

Slika 6: Izgled makrostrukture premaza na osnovi AAM. Struktura premaza je kompaktna. Povečava 100x 
A. DUFKA et al.: THE DEVELOPMENT OF NEW TYPES OF SECONDARY PROTECTION ...

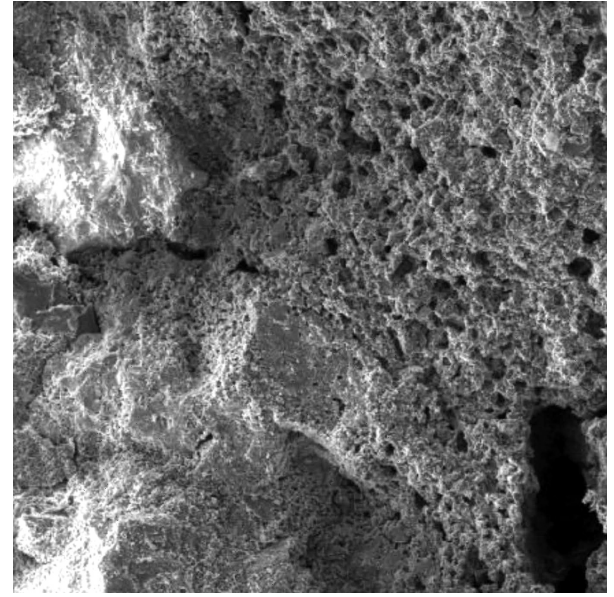

Figure 7: To increase the adhesion to the substrate, AAM coating was modified with polymer dispersion. 100× magnification

Slika 7: Za povečanje adhezije na podlago, je bil AAM premaz modificiran z disperzijo polimera. Povečava 100x

this case, the decrease in water-tightness is associated with the impaired compactness of the coating due to defects (occurrence of microcracks, etc.). In the AAM coating, the changes due to the test environment were not so distinct.

\subsection{Analysis of microstructure with the electron micro- scope}

Using the electron microscope, the microstructure of individual materials and, in particular, the changes caused by the effects of an aggressive environment were analysed. Hence, this method was primarily considered as comparative; it means that the samples were primarily compared prior to and after the exposure to laboratory conditions.

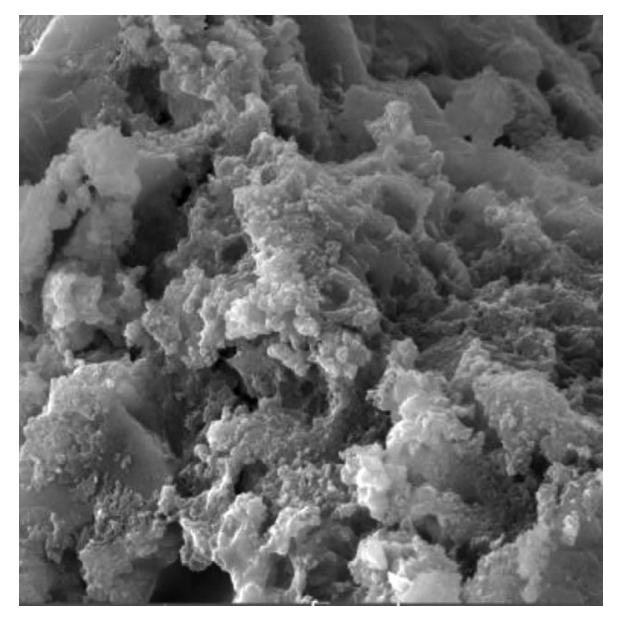

Figure 8: Pseudomorphs of calcium hydrosilicate gels in AAM-based coating - a sample placed at laboratory conditions. 5000× magnification

Slika 8: Psevdomorfija kalcijevega hidrosilikatnega gela v premazu na osnovi AAM - vzorec izpostavljen laboratorijskim pogojem. Povečava $5000 \times$

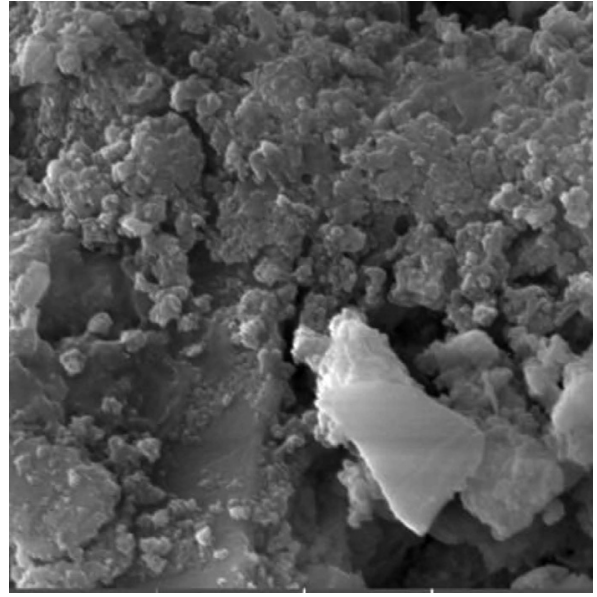

Figure 9: View of the microstructure of AAM-based coating after a 6-month exposure to the test environment. 5000× magnification Slika 9: Izgled mikrostrukture premaza na osnovi AAM, po šest mesečni izpostavitvi preizkusnemu okolju. Povečava 5000x

\section{Evaluation}

The analysis of the microstructure with the electron microscope confirmed and further extended our knowledge obtained during the previous determinations. The resistance of the AAM coating to the effects of the test environment was confirmed. The fact that the structure of AAM coating is relatively compact is shown in Figure 6. To increase the adhesion to the substrate, AAM coating was modified with a polymer dispersion. This fact resulted in a partial increase in the porosity of the coating structure (Figure 7). Pseudomorphs of calcium hydrosilicate gels represent a dominant component of AAM-based coating (Figure 8). Calcium hydrosilicate phases are still dominant components of AAM-based coating also after a 6-month exposure to the test environment (Figure 9). Special attention was focused on the analysis of the interface AAM paint/con-

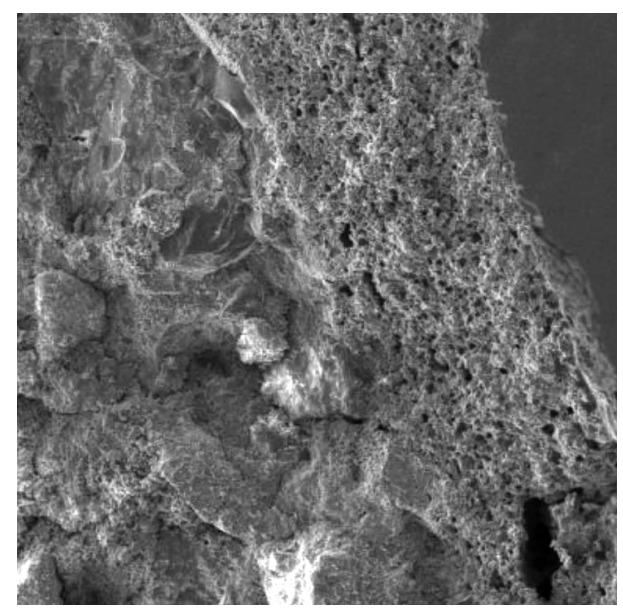

Figure 10: View of the AAM coating/concrete substrate interface after a 6-month exposure to the test environment. 600× magnification Slika 10: Izgled stika AAM premaza/betonska podlaga po izpostavitvi šest mesecev preizkusnemu okolju. Povečava 600x 
A. DUFKA et al.: THE DEVELOPMENT OF NEW TYPES OF SECONDARY PROTECTION ...

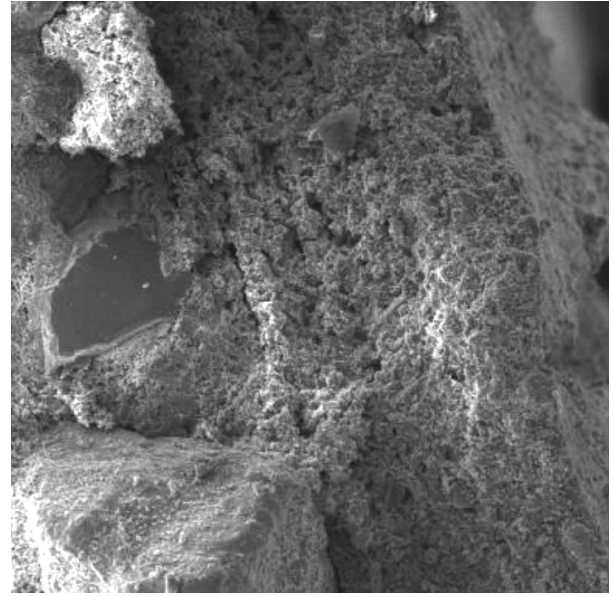

Figure 11: Detailed view of the AAM coating/concrete substrate interface after a 6-month exposure to the test environment. 1000x magnification

Slika 11: Detajl izgleda stika AAM premaz/betonska podlaga, po izpostavitvi šest mesecev preizkusnemu okolju. Povečava 1000×

12)

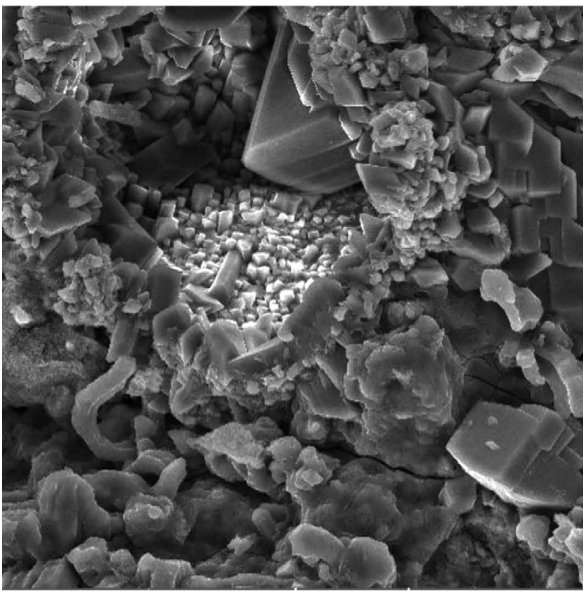

13)

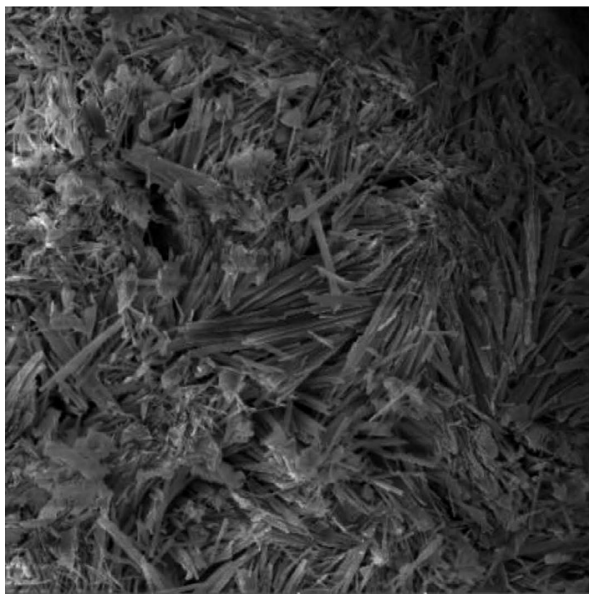

Figures 12 and 13: View of the structure of surface layers of the concrete that was protected with acrylate copolymer-based coating and exposed to an aggressive environment for a period of 6 months. $4200 \times$ magnification

Sliki 12 in 13: Izgled zgradbe površinske plasti betona, ki je bil zaščiten s prematom na osnovi akrilatnega polimera in izpostavljenega agresivnemu okolju za dobo šest mesecev. Povečava 4200×

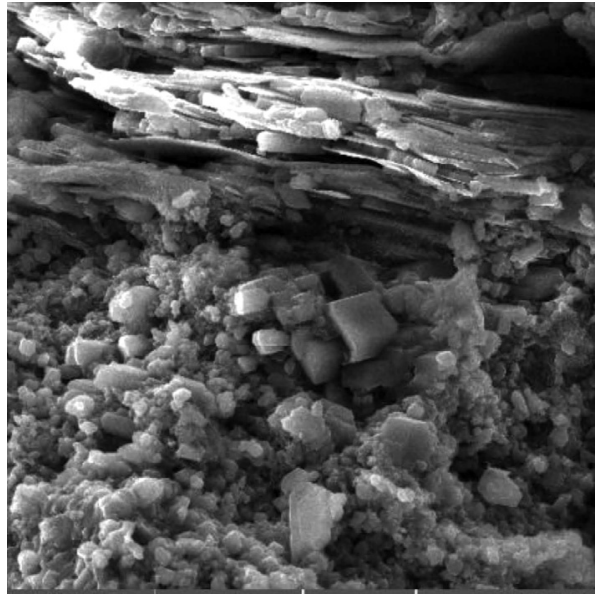

Figure 14: View of the structure of uncoated concrete after a threemonth exposure to the test environment. The creation of corrosive products (gypsum pseudomorphs) in the microstructure is evident. 4200× magnification

Slika 14: Izgled zgradbe iz nezaščitenega betona po treh mesecih izpostavitve preizkusnemu okolju. Viden je nastanek korozijskih produktov (psevdomorfija mavca). Povečava 4200×

crete. It was found that the interface structure is compact. The absence of any corrosive new formations both in the coating and in the substrate is evident (Figures $\mathbf{1 0}$ and 11).

Conversely, the surface layers of the concrete protected with the coating based on acrylate copolymer have proven that the exposure to an aggressive environment cause negative changes in the microstructure of the surface layers of the concrete substrate. It was found that the microstructure of this concrete has been subject to negative changes - new formations of ettringite and gypsum have been created (Figures 12 and 13).

The degradation due to the test environment has shown itself to an extreme degree in the concrete that was not protected with any coating during the exposure.

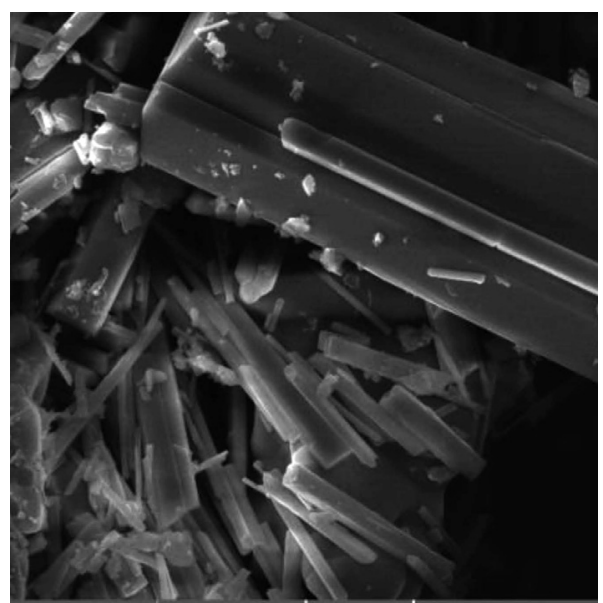

Figure 15: Detailed view of corrosive new formations (gypsum) in the microstructure of cement matrix after a 6-month exposure to the test environment. 4500× magnification

Slika 15: Detajl korozijskih produktov (mavec) v betonski osnovi po izpostavitvi šest mesecev preizkusnemu okolju. Povečava 4500× 
A. DUFKA et al.: THE DEVELOPMENT OF NEW TYPES OF SECONDARY PROTECTION ...

In that case, the development of corrosive new formations (mainly of gypsum) was essential (Figures 14 and 15).

\section{CONCLUSIONS}

The performed experiments have confirmed that the synergistic effect of the concentrated solution of ammonium sulphate and the increased temperature results in a significant degradation of the coating based on acrylate copolymer. In this type of coating, the utility parameters have decreased despite the fact that the coating is designed for chemically aggressive environments. It is just the synergistic effect of chemicals and, in particular, of increased temperatures that can be designated as the primary cause of such a negative effect of the test environment.

In turn, positive results have been achieved with the coating based on alkali-activated slag using appropriate types of modifying additives. It has been confirmed that this type of coating is able to effectively withstand the joint effect of chemically aggressive substances and increased temperature. For any of the parameters observed, no decrease greater than $25 \%$ has been found. The listed findings unambiguously confirm the potential for the use of material based on alkali-activated substances for the secondary protection of reinforced concrete structures exposed to extreme conditions. The development of this type of coating has not been completed yet, but it is still ongoing. In the following stages, attention will be paid, for example, to the possibility of having the autogenous shrinkage limited using nanosized reinforcements, to the application of modifying additives; hence, the analysis of the AAM coating/concrete substrate interface, etc. will become an important research area.

\section{Acknowledgements}

This research was conducted with the financial help of project GAČR 14-25504S Research of Behaviour of Inorganic Matrix Composites Exposed to Extreme Conditions and the project No. LO1408 AdMaS UP - Advanced Materials, Structures and Technologies, supported by Ministry of Education, Youth and Sports under the National Sustainability Programme I.

\section{REFERENCES}

${ }^{1}$ P. Rovnanik, The influence of high temperatures on building materials based on alkali-activated binders, Habilitation thesis, 2012, Brno University of Technology, Faculty of Civil Engineering

${ }^{2}$ N. R. Rakhimova, Z. V. Rakhimov, Alkali-activated cements and mortars based on blast furnace slag and red clay brick waste, Materials and Design, 85 (2015), 324-331, doi:10.1016/j.matdes. 2015.06.182

${ }^{3}$ B. Yuan, Q. L. Yu, H.J.H. Brouwers, Reaction kinetics, reaction products and compressive strength of ternary activators activated slag designed by Taguchi method, Materials and Design, 86 (2015), 878-886, doi:10.1016/j.matdes.2015.07.077

${ }^{4}$ A. Dufka, J. Kosikova, L. Meszarosova, The use of Geopolymers in Rehabilitation of Reinforced Concrete structures, Advanced Materials Research, 785-786 (2013), 224-230, doi:10.40288/ www.scientific.net/amr.785-786.224

${ }^{5}$ P. Thometzek, A. Ludwig, A. Karbach, K. Kohler, Effects of morphology and surface treatment of inorganic pigments on waterborne coating properties, Progress in Organic Coatings. 36 (1999) 4, 201-209, doi:10.1016/S0300-9440(99)00037-5

${ }^{6}$ K. Dvořak, M. Fridrichova, P. Dobrovolny, Influence of different grinding types on granulometry of recycled glass, Construction Materials and Structures, 2014, 305-310, doi:10.3233/978-161499-466-4-305

${ }^{7}$ J.A. Golczewski, H.J. Seifert, F. A Aldinger, Thermodynamic model of amorphous silicates, 22 (1998) 3, 381-396, doi:10.1016/S03645916(98)00038-8 